\title{
CARBON CONTENT IN AMAZONIAN OXISOLS AFTER FOREST CONVERSION TO PASTURE ${ }^{(1)}$
}

\author{
Mário Lopes da Silva Júnior ${ }^{(2)}$, Thierry Desjardins ${ }^{(3)}$, Max $\operatorname{Sarrazin}^{(4)}$, Vânia \\ Silva de Melo ${ }^{(5)}$, Paulo Fernando da Silva Martins ${ }^{(6)}$, Elaine Rodrigues \\ Santos $^{(7)} \&$ Claudio José Reis de Carvalho ${ }^{(8)}$
}

\begin{abstract}
Soil plays an important role in the $\mathrm{C}$ cycle, and substitution of tropical forest by cultivated land affects $\mathrm{C}$ dynamic and stock. This study was developed in an area of expansion of human settlement in the Eastern Amazon, in Itupiranga, State of Pará, to evaluate the effects of native forest conversion to Brachiaria brizantha pasture on $\mathrm{C}$ contents of a dystrophic Oxisol. Soil samples were collected in areas of native forest (NF), of 8 to 10 year old secondary forest (SF), 1 to 2 year old SF (P1-2), 5 to 7 year old SF (P5-7), and of 10 to 12 year old SF (P10-12), and from under pastures, in the layers $0-2,2-5$ and $5-10 \mathrm{~cm}$, to evaluate $\mathrm{C}$ levels and stocks and carry out separation of OM based on particle size. After deforestation, soil density increased to a depth of $5 \mathrm{~cm}$, with greater increase in older pastures. Variation in $\mathbf{C}$ levels was greatest in the top soil layer; $\mathbf{C}$ contents increased with increasing pasture age. In the layers $2-5$ and $5-10 \mathrm{~cm}, \mathrm{C}$ content proved to be stable for the types of plant cover evaluated. Highest $\mathrm{C}$ concentrations were found in the silt fraction; however, $\mathrm{C}$ contents were highest in the clay fraction, independent of the plant cover. An increase in $\mathrm{C}$ associated with the sand fraction in the form of little decomposed organic residues was observed in pastures, confirming greater sensitivity of this fraction to change in soil use.
\end{abstract}

Index terms: soil carbon stock, particle-size fractions, tropical soil, Amazon rain forest.

\footnotetext{
(1) From the Doctoral Thesis of the first author presented at Universidade Federal Rural da Amazônia. Received for publication in October 2008 and approved August 2009.

(2) Professor, Agricultural Science Institute of Universidade Federal Rural da Amazônia - UFRA. CEP 66077-570 Belém (PA). Brazil. E-mail: mario.silva@ufra.edu.br

${ }^{(3)}$ Researcher, Institut de Recherche pour le Développement, IRD. UMR BIOEMCO, 32 rue Henri Varagnat, 93143 Bondy Cedex, France. E-mail: thierry.desjardins@ird.fr

(4) Researcher, IRD, UMR BIOEMCO, route de Montabo, 97323 Cayenne Cedex, Guyane Française

${ }^{(5)}$ Researcher, UFRA, CAPES post-Doctoral grant holder. CEP 66077-570 Belém (PA). Brazil. E-mail: vlgmelo@yahoo.com.br

${ }^{(6)}$ Professor, Agricultural Science and Rural Development Center, Universidade Federal do Pará - UFPA. E-mail: pfsm@ufpa.br

(7) Masters in Agronomy in progress, Capes grant holder, UFRA. CEP 66077-570 Belém (PA). Brazil. E-mail: elainesanufra@yahoo.com.br

${ }^{(8)}$ Researcher, Embrapa Amazônia Oriental. CEP 66095-100 Belém (PA). Brazil. E-mail: claudio.reis@pq.cnpq.br
} 


\title{
RESUMO: VARIAÇÃO DO CONTEÚDO DE CARBONO ORGÂNICO EM LATOSSOLO DA AMAZÔNIA APÓS SUBSTITUIÇÃO DA FLORESTA POR PASTAGENS
}

\begin{abstract}
O solo desempenha importante papel no ciclo do C, porém a substituição da floresta tropical por áreas cultivadas altera a dinâmica e o estoque desse elemento. Em uma frente pioneira de colonização no município de Itupiranga (PA), na Amazônia Oriental, foi desenvolvido este estudo com o objetivo de avaliar as consequências da substituição de floresta nativa por pastagens de Brachiaria brizantha no conteúdo de C de um Latossolo Amarelo distrófico. As amostras de solo foram coletadas em área de floresta nativa (FN), floresta secundária de 8-10 anos (FS), pastagens de 1-2 anos (P1-2), de 5-7 anos (P5-7) e de 1012 anos (P10-12), nas camadas de 0-2, 2-5 e 5-10 cm, para avaliar os teores e o estoque de $C$ e realizar um fracionamento granulométrico da matéria orgânica. Após o desmatamento, a densidade do solo aumentou até a profundidade de $5 \mathrm{~cm}$, sendo esse aumento maior nas pastagens mais antigas. As maiores mudanças no conteúdo de $C$ ocorreram na camada superior do solo, havendo aumento nesse conteúdo com o tempo de implantação das pastagens. Nas camadas de 2-5 e 5-10 cm, o conteúdo de C se mostrou estável entre os tipos de cobertura vegetal avaliados. As maiores concentrações de $C$ foram encontradas na fração silte, mas os maiores conteúdos de Cocorreram na fração argila, independentemente do tipo de cobertura vegetal. Um aumento da quantidade de C associado à fração areia, na forma de resíduos orgânicos pouco decompostos, foi observado nas pastagens, confirmando a maior sensibilidade dessa fração às mudanças de uso do solo.
\end{abstract}

Termos de indexação: estoque de carbono no solo, fracionamento granulométrico, solo tropical, floresta amazônica.

\section{INTRODUCTION}

To substitute natural forest by pasture is a common practice in the Brazilian Amazon, mainly in the States of Pará and Rondônia (Moraes et al., 1996; Fearnside \& Barbosa, 1998). This change in plant cover causes an imbalance that can modify biological (Luizão et al., 1999; Melo, 2007), physical (Desjardins et al., 1994; Moraes et al., 1996) and chemical properties of the soil (Smith \& Bastos, 1984; Longo \& Espíndola, 2000), and especially soil OM (SOM) (Martins et al., 1990; Bernoux et al., 1999; Desjardins et al., 2004).

When native vegetation is substituted by agricultural systems in tropical regions, SOM stocks can be greatly reduced as a consequence of physical disturbance of the soil, exposing the organic matter $(\mathrm{OM})$ to intense microbial activity, which results in rapid decomposition of $\mathrm{OM}$ in the soil (Silva \& Machado, 2000; Mielniczuk et al., 2003). In the Amazon, although in some cases forest substitution by pasture reduces SOM contents, (Desjardins et al., 1994; Trumbore et al., 1995), in other cases higher C levels were observed several years after pasture implantation, which exceeded even the contents observed in forest areas (Choné et al., 1991; Koutika et al., 1997; Desjardins et al., 2004). According to Desjardins et al. (2004), these opposite tendencies of soil C content development are caused by factors such geographical location and soil type, grass species, and cultural practices and management techniques.
The variation of soil $\mathrm{C}$ content has mostly been studied using physical fractionation techniques for $\mathrm{OM}$, to separate fractions that differ from each other in nature, dynamics and function (Desjardins et al., 1994, 2004; Bird et al., 2000; Christensen, 2001; Roscoe et al., 2001). The less destructive nature of physical than chemical fractionation techniques, for being more related to in situ functions and structure of SOM makes them important tools for SOM dynamics analysis (Christensen, 2001; Rangel \& Silva, 2007). Physical fractionation shows that OM dynamics are intimately related to soil texture (Martins et al., 1989; Feller \& Beare, 1997; Silver et al., 2000; Desjardins et al., 2004). The proportion of organic $C$ in sandy soil in form of slightly decomposed plant residues is therefore greater, making such soils more fragile from the point of view of land use, since this fraction, devoid of physical protection, is easily mineralized by microorganisms (Feller \& Beare, 1997). On the other hand, greater $\mathrm{C}$ contents in the silt and clay fractions were verified in clayey soils (Desjardins et al., 2004) due to the greater stability of organic mineral compounds formed (Sánchez, 1981) making these soil fractions more persistent. Different organic compartments respond distinctly to soil use and management practices (Balesdent et al., 1998; Bernoux et al., 1999). In summary, the implantation of pastures by slash and burn agriculture in the Amazon region modifies soil properties, leading in particular to alterations in $\mathrm{C}$ stock distribution in the different soil particle-size fractions (Desjardins et al., 1994, 2004; Koutika et al., 1997; Bernoux et al., 1999). 
Research on the cycle and dynamics of $\mathrm{C}$ in soil after substitution of forest by pasture in the Amazon region showed varied results depending on region, soil type and land use. The objective of this paper was to study the impact of forest substitution by pasture on $\mathrm{C}$ levels and distribution associated with different $\mathrm{OM}$ fractions in a dystrophic Oxisol in the Eastern Amazon region.

\section{MATERIALS AND METHODS}

The study was carried out in the Southeast of the State of Pará, microregion of Marabá, in the settlement Benfica $\left(5^{\circ} 16^{\prime} 00\right.$ ” S; $49^{\circ} 50$ ' 00 ” W), at a distance of $80 \mathrm{~km}$ from the center of Itupiranga, PA, in the Eastern Amazon. The landscape of Benfica consists of elongated hills developed from a biotite monzogranite mother-rock of the Brazilian Shield (Paleoproterozoic). The soil in the study area is predominantly dystrophic Oxisol with clayey texture, which covers approximately $2 / 3$ of the surface and occurs in areas with higher elevation. Cambissols are found on lower parts of slopes and Gleissols are found in low-lying areas (Simões, 2004). The climate of the microrregion Marabá is Awi, according to Köppen, corresponding to humid tropical climates with a definite dry season between May and September, average annual temperature of $26^{\circ} \mathrm{C}$ and average annual precipitation around 2,000 $\mathrm{mm}$ (De Reynal, 1995). All studied sites were located in the upper part of the landscape, where dystrophic Oxisol with clayey texture occurs.
Soil sampling was carried out in May 2004, at depths of $0-2,2-5$ and $5-10 \mathrm{~cm}$, in 15 sample areas selected at the tops of slopes (three areas for each soil management and use system), in a $100 \mathrm{~m}$ long transect perpendicular to the slope declivity at 20 sampling points to form composite samples that were air-dried, ground and filtered through $2 \mathrm{~mm}$ mesh sieve (airdried fine earth - ADFE). Soil management and use types were: (a) native forest (NF): a selectively logged, humid tropical forest area; this area was chosen as a reference for comparison of the study properties; (b) capoeira or secondary forest (SF): secondary forest of 8-10 years after slash and burn of original forest and cultivation of one year of annual crops (rice and cassava); (c) grass pastures (Brachiaria brizantha) for 1 to 2 years (P1-2), 5 to 7 years (P5-7) and 10 to 12 years (P10-12): areas used for extensive cattle-raising without control of the stocking rate, with a density of approximately $1 \mathrm{au} \mathrm{ha}^{-1}$, using the conventional livestock system in which the original vegetation had been removed, and after burning, grass was planted by broadcasting seed. In this system no phytosanitary control, no liming or fertilization is applied (Biri Kassoum \& Maitre d'Hotel, 2002).

ADFE samples were utilized in textural analysis and particle-size fractionation of OM. The textural analysis was performed after OM destruction with $\mathrm{H}_{2} \mathrm{O}_{2}$, using the pipette method (Embrapa, 1997). For soil density analysis, six undisturbed samples were collected from each system and depth, using 2,3 and $5 \mathrm{~cm}$ high volumetric rings. The mean soil chemical properties per depth of the acidic, dystrophic Oxisol poor in exchangeable bases under study are shown in table 1 (Embrapa, 1997).

Table 1. Oxisol chemical property averages by depth in different soil management and use

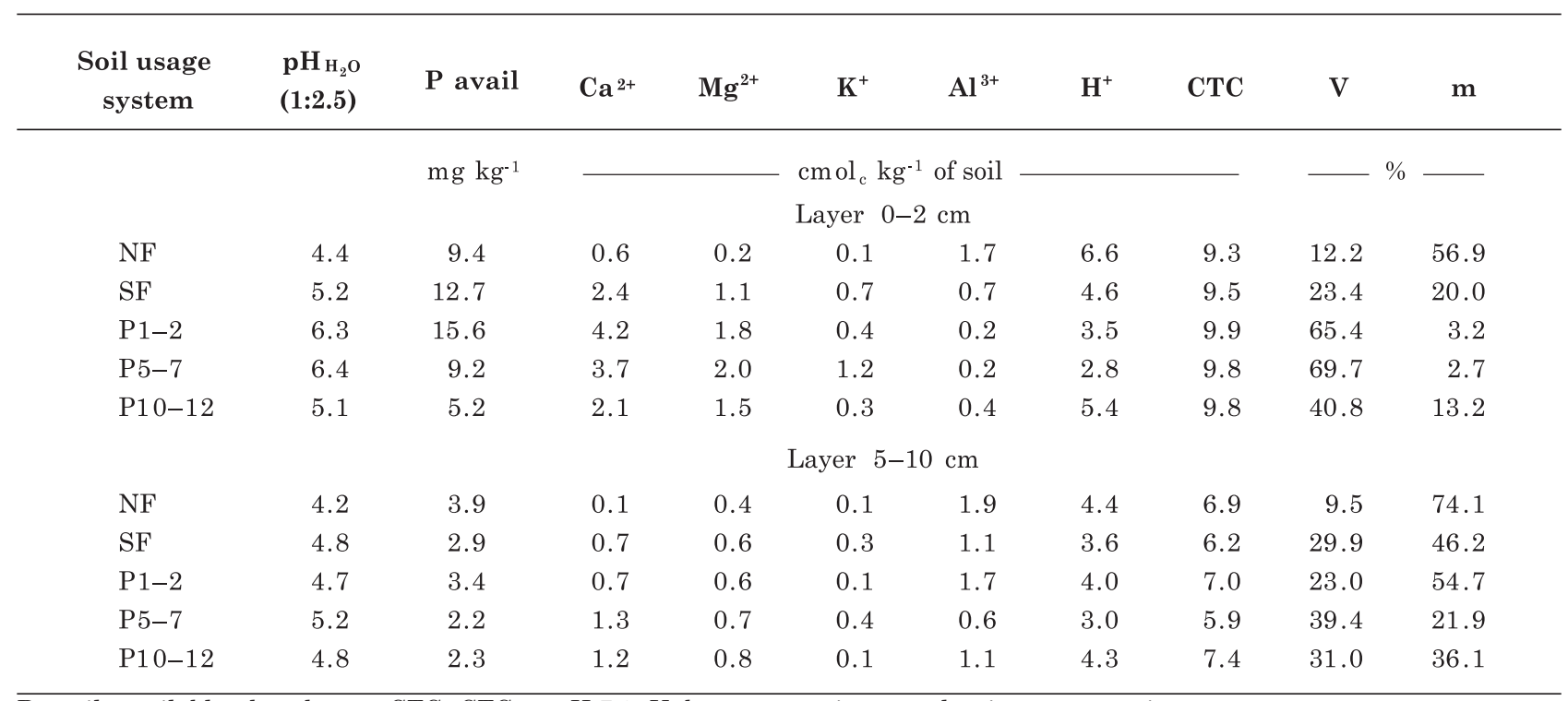

P avail: available phosphorus; CTC: CTC at $\mathrm{pH}$ 7.0; V: base saturation; m: aluminum saturation. 
Particle-size fractionation of soil OM was performed by the method of Gavinelli et al. (1995), using $20 \mathrm{~g}$ of ADFE, initially dispersed by mechanical agitation in $400 \mathrm{~mL}$ water with $100 \mathrm{~cm}^{3}$ soda resin (VETEC Amberlite Ira 120) for $16 \mathrm{~h}$. The fraction $>53 \mu \mathrm{m}$, containing plant residues along with mineral particles, was wet-separated in a $53 \mu \mathrm{m}$ sieve. The $0-2 \mu \mathrm{m}$ and $0-53 \mu \mathrm{m}$ fractions were separated by sedimentation in water. The silt + clay fraction $(0-53 \mu \mathrm{m})$ was obtained by total collection of the suspension. The clay fraction $(0-2 \mu \mathrm{m})$ was obtained by collecting aliquots from the suspension based on the sedimentation time of this fraction. All fractions were dried in a forced-air oven at $60^{\circ} \mathrm{C}$.

Total organic $\mathrm{C}$ was determined by dry combustion of a sample aliquot of each soil particle-size fraction, sieved through $0.149 \mathrm{~mm}$ mesh, in a CHNS elemental analyzer (LECO), and expressed in $\mathrm{g} \mathrm{kg}^{-1}$. The $\mathrm{C}$ stock in the different systems and at each soil depth was calculated based on the following formula: $\mathrm{C}$ stock $\left(\mathrm{Mg} \mathrm{ha}^{-1}\right)=\mathrm{C}$ level $\left(\mathrm{g} \mathrm{kg}^{-1}\right) \times \mathrm{Ds} \times \mathrm{T} / 10$, where Ds $=$ soil density at depth $\left(\mathrm{g} \mathrm{cm}^{-3}\right)$ and $\mathrm{T}=$ thickness of soil layer $(\mathrm{cm})$. The silt fraction $\mathrm{C}(2-53 \mu \mathrm{m})$ was calculated as the difference between silt + clay fraction $\mathrm{C}(0-53 \mu \mathrm{m})$ and clay fraction $\mathrm{C}(0-2 \mu \mathrm{m})$.

A completely randomized design was used and the results for the variables studied were subjected to variance analysis of the effects of land use type for each depth. Averages were compared by Duncan's test (5\% error probability) using the statistical program SAEG 8.1.

\section{RESULTS AND DISCUSSION}

\section{Physical properties}

No significant variation in soil texture within each layer of the studied areas was observed (Table 2). On these areas, located in flat places or with slight slopes, surface erosion which can occur very rapidly after forest substitution when rainfall intensity is high had no significant effect and did not affect the soil textural composition, providing good experimental conditions for a comparison of the texture-dependent variables studied, e.g., soil density and C content (Martins et al., 1990; Desjardins et al., 2004). The lowest and highest clay levels, respectively, were observed in the secondary forest (SF) and the 10 to 12 year old (P10 12) pasture area. The clay content varying from 320 to $500 \mathrm{~g} \mathrm{~kg}^{-1}$ soil confirmed the soil classification as clayey, except in the 0-2 cm layer of the $\mathrm{SF}$ and in the 1-to-2-year-old pasture (P1-2) areas (Simões, 2004).

Soil density (Ds) values varied from 1.05 to $1.45 \mathrm{~g} \mathrm{~cm}^{-3}$ (Table 2). In the surface layer, the lowest value occurred in native forest (NF), followed by SF and $\mathrm{P} 1-2$. Values were highest in the pastures $\mathrm{P} 5-7$ and $\mathrm{P} 10-12$, differing significantly from $\mathrm{NF}$ and $\mathrm{SF}$ areas. In the $2-5 \mathrm{~cm}$ layer, soil density of the native forest area only differed from pasture areas P5-7 and $\mathrm{P} 10-12$. In the $5-10 \mathrm{~cm}$ layer, there was no Ds variation in function of plant cover. Note also that Ds increased with greater depth under all soil use types, with greatest increases between the layers

Table 2. Average grades of total clay, silt, and sand and soil density (Ds) in different layers of a dystrophic Oxisol with clayey texture in function of land use system

\begin{tabular}{|c|c|c|c|c|c|}
\hline Soil usage system & Clay & Silt & Sand & Silt/Clay & Ds \\
\hline & \multicolumn{3}{|c|}{ - $\mathrm{kg}^{-1}$ soil } & & \multirow[t]{2}{*}{$\mathrm{g} \mathrm{cm}^{-3}$} \\
\hline & & & $0-2 \mathrm{~cm}$ Layer & & \\
\hline NF & $367^{\mathrm{ns}}$ & $46^{\text {ns }}$ & $587^{\mathrm{ns}}$ & 0.13 & $1.05 \mathrm{~b}$ \\
\hline SF & 322 & 53 & 625 & 0.16 & $1.09 \mathrm{~b}$ \\
\hline $\mathrm{P} 1-2$ & 344 & 68 & 588 & 0.20 & $1.27 \mathrm{ab}$ \\
\hline $\mathrm{P} 5-7$ & 353 & 74 & 573 & 0.21 & $1.38 \mathrm{a}$ \\
\hline \multirow[t]{2}{*}{$\mathrm{P} 10-12$} & 444 & 70 & 486 & 0.16 & $1.36 \mathrm{a}$ \\
\hline & & & $2-5 \mathrm{~cm}$ Layer & & \\
\hline NF & $443^{\text {ns }}$ & $49^{\text {ns }}$ & $508^{\mathrm{ns}}$ & 0.11 & $1.13 \mathrm{~b}$ \\
\hline SF & 373 & 48 & 579 & 0.13 & $1.21 \mathrm{ab}$ \\
\hline $\mathrm{P} 1-2$ & 442 & 47 & 511 & 0.11 & $1.27 \mathrm{ab}$ \\
\hline P5-7 & 443 & 47 & 510 & 0.11 & $1.45 \mathrm{a}$ \\
\hline \multirow[t]{2}{*}{$\mathrm{P} 10-12$} & 476 & 69 & 455 & 0.14 & $1.40 \mathrm{a}$ \\
\hline & & & 5-10 cm Layer & & \\
\hline NF & $503^{\text {ns }}$ & $50^{\mathrm{ns}}$ & $447^{\mathrm{ns}}$ & 0.10 & $1.29^{\mathrm{ns}}$ \\
\hline $\mathrm{SF}$ & 416 & 56 & 528 & 0.13 & 1.32 \\
\hline $\mathrm{P} 1-2$ & 499 & 53 & 448 & 0.11 & 1.35 \\
\hline $\mathrm{P} 5-7$ & 504 & 50 & 446 & 0.10 & 1.40 \\
\hline $\mathrm{P} 10-12$ & 506 & 66 & 428 & 0.13 & 1.44 \\
\hline
\end{tabular}

Averages followed by the same letter in the column, in the same layer, did not differ significantly by the Duncan test with an error margin of $5 \%$; ${ }^{\text {ns: }}$ not significant. 
0-2 $\mathrm{cm}$ and $5-10 \mathrm{~cm}$ in $\mathrm{NF}(+23 \%)$ and $\mathrm{SF}(+21 \%)$ and the lowest increase in $\mathrm{P} 5-7$ (+ $1.4 \%)$. Increasing pressure on the soil by animal trampling, mainly in the top layer largely explains the density increase over time of use in pastures.

Araújo et al. (2004) observed that in the surface layer of a Yellow dystrophic Ultisol in the State of Acre (Western Amazon region), soil density increased after substitution of native plants $\left(\mathrm{Ds}=1.40 \mathrm{~g} \mathrm{~cm}^{-3}\right)$ by pasture $\left(\mathrm{Ds}=1.73 \mathrm{~g} \mathrm{~cm}^{-3}\right)$. The authors attributed this increase to cattle trampling and the greater susceptibility of the soil to wetting and drying cycles than under native forest. Soil density increase in function of increasing pasture age planted in former forest areas was also observed by other authors in the Amazon region (Bernoux et al., 1999; Desjardins et al., 2004).

\section{Particle size fractionation of organic material}

There was no significant difference in the weight distribution resulting from soil particle-size fractionation for all of soil use types and layers (Table 3). Greatest variation was observed in the 2 $53 \mu \mathrm{m}$ or silt fraction, which is probably due to an incomplete dispersion of micro-aggregate particles with the soda resin used in the particle-size fractionation procedure. The method of Gavinelli et al. (1995) was only able to recover an average of $86 \%$ of the clay fraction for the textural analysis, showing that a small part of the clay fraction remained in the

Table 3. Average mass of particle size fractions for the three soil layers, collected down to $10 \mathrm{~cm}$ depth in a dystrophic Oxisol with clayey texture in function of land use system

\begin{tabular}{|c|c|c|c|}
\hline $\begin{array}{c}\text { Soil usage } \\
\text { system }\end{array}$ & $0-2 \mu \mathrm{m}$ & $2-53 \mu \mathrm{m}$ & $53-2000 \mu \mathrm{m}$ \\
\hline \multicolumn{4}{|c|}{$\mathrm{g} \mathrm{kg}^{-1}$ soil } \\
\hline & \multicolumn{3}{|c|}{$0-2 \mathrm{~cm}$ Layer } \\
\hline NF & $316^{\mathrm{ns}}$ & $88^{\mathrm{ns}}$ & $585^{\mathrm{ns}}$ \\
\hline SF & 272 & 111 & 614 \\
\hline $\mathrm{P} 1-2$ & 291 & 88 & 606 \\
\hline P $5-7$ & 359 & 91 & 531 \\
\hline \multirow[t]{2}{*}{$\mathrm{P} 10-12$} & 327 & 117 & 538 \\
\hline & \multicolumn{3}{|c|}{$2-5 \mathrm{~cm}$ Layer } \\
\hline NF & $375^{\mathrm{ns}}$ & $91^{\mathrm{ns}}$ & $519 \mathrm{~ns}$ \\
\hline $\mathrm{SF}$ & 345 & 89 & 560 \\
\hline $\mathrm{P} 1-2$ & 361 & 75 & 547 \\
\hline $\mathrm{P} 5-7$ & 432 & 74 & 480 \\
\hline \multirow[t]{2}{*}{ P10-12 } & 377 & 104 & 510 \\
\hline & \multicolumn{3}{|c|}{ 5-10 cm Layer } \\
\hline $\mathrm{NF}$ & $399 \mathrm{~ns}$ & $101^{\mathrm{ns}}$ & $479 \mathrm{~ns}$ \\
\hline $\mathrm{SF}$ & 371 & 85 & 526 \\
\hline $\mathrm{P} 1-2$ & 424 & 72 & 482 \\
\hline $\mathrm{P} 5-7$ & 472 & 64 & 450 \\
\hline $\mathrm{P} 10-12$ & 436 & 90 & 465 \\
\hline
\end{tabular}

ns: not significant for the same layer by the Duncan test with an error margin of $5 \%$ silt fraction. This effect could have occurred on account of the linkage of clay particles or $\mathrm{Fe}$ and $\mathrm{Al}$ oxides and hydroxides to the humified OM, forming stable micro-aggregates with diameters $>2 \mu \mathrm{m}$, in which SOM would be protected from the attack by chemical and microbial agents (Feller \& Beare, 1997; Balesdent et al., 1998; Christensen, 2001), making these micro-aggregates very stable and difficult to rupture.

Several studies on particle-sized fractionation of soil OM using similar or different fractionation methods drew similar conclusions (Desjardins et al., 1994; 2004; Roscoe et al., 2001). Similarly, Balesdent et al. (1998) observed lower levels for finer soil fractions $(<20 \mu \mathrm{m})$ when OM was not destroyed in a study of $\mathrm{OM}$ content variability in areas of a forest-maize sequence, indicating that such fractions were not completely dispersed.

\section{Carbon concentration in soil particle-size fractions}

Carbon concentrations differ significantly in the particle-size fractions; highest values were found in the silt fraction $(2-53 \mu \mathrm{m})$ at all depths studied (Table 4). In this fraction, the $\mathrm{C}$ concentration varied from 48.9 to $112.9 \mathrm{~g} \mathrm{~kg}^{-1}$. In the sand fraction (53$2,000 \mu \mathrm{m})$, the $\mathrm{C}$ concentration was lowest and the reduction with increasing depth greatest, evidencing the effect of deposition of plant residues (leaves, branches, flowers) on the soil surface. On the other hand, the percentage of reduction in $\mathrm{C}$ concentration in this fraction with increasing depth was lowest in NF, probably as a result of a more uniform distribution of OM by organic particle transportation processes in the soil profile.

The reduction of $\mathrm{C}$ concentration with increasing depth in the clay fraction $(0-2 \mu \mathrm{m})$ was the lowest in all fractions, with an average of $27 \%$ for the $2-5 \mathrm{~cm}$ layer and $38 \%$ for the $5-10 \mathrm{~cm}$ layer. This more gradual reduction was partly due to the greater stability of OM associated with clays, consisting of humified compounds which are chemically or physically protected and more resistant to mineralization (Tisdall \& Oades, 1982; Desjardins et al., 1994; Feller \& Beare, 1997).

\section{Total C distribution in soil and particle-size fractions}

The soils of the five land use systems did not differ largely within each fraction with respect to $\mathrm{C}$ content, whether for soil, corresponding to the sum of the three fractions, nor for each particle-size fraction (Figure 1).

In the 0-2 cm layer, the $\mathrm{C}$ content was lowest in NF. A value similar to native forest was found in P1-2 and there was a tendency of increasing $\mathrm{C}$ content with pasture age, as also observed in SF. In the 2$5 \mathrm{~cm}$ layer, this $\mathrm{C}$ increase was not repeated in the SF use system, and the tendency to increase with 
Table 4. Carbon concentration of particle-size fractions in different layers of Oxisol, with different land use system

\begin{tabular}{|c|c|c|c|}
\hline \multirow{2}{*}{ Soil use } & \multicolumn{3}{|c|}{$\begin{array}{l}\text { Carbon of particle-size } \\
\text { fractions of soil }\end{array}$} \\
\hline & $0-2 \mu \mathrm{m}$ & $2-53 \mu \mathrm{m}$ & $53-2000 \mu \mathrm{m}$ \\
\hline & \multicolumn{3}{|c|}{$\mathrm{g} \mathrm{kg}^{-1}$ fraction } \\
\hline & \multicolumn{3}{|c|}{$0-2 \mathrm{~cm}$ Layer } \\
\hline $\mathrm{NF}$ & $34.1^{\mathrm{ns}}$ & $106.6^{\mathrm{ns}}$ & $5.8^{\mathrm{ns}}$ \\
\hline $\mathrm{SF}$ & 37.7 & 106.6 & 9.1 \\
\hline $\mathrm{P} 1-2$ & 34.3 & 89.8 & 8.8 \\
\hline $\mathrm{P} 5-7$ & 28.9 & 112.9 & 11.7 \\
\hline $\mathrm{P} 10-12$ & 33.9 & 97.4 & 9.8 \\
\hline Average & $33.8 \mathrm{~B}$ & $102.7 \mathrm{~A}$ & $9.0 \mathrm{C}$ \\
\hline \multicolumn{4}{|c|}{$2-5 \mathrm{~cm}$ Layer } \\
\hline NF & $25.4^{\mathrm{ns}}$ & $67.5^{\mathrm{ns}}$ & $2.8^{\mathrm{ns}}$ \\
\hline $\mathrm{SF}$ & 25.9 & 67.4 & 2.7 \\
\hline $\mathrm{P} 1-2$ & 26.0 & 67.3 & 3.1 \\
\hline P5-7 & 22.2 & 86.7 & 5.4 \\
\hline P10-12 & 24.4 & 64.9 & 4.4 \\
\hline Average & $24.9 \mathrm{~B}$ & $70.8 \mathrm{~A}$ & $3.7 \mathrm{C}$ \\
\hline \multicolumn{4}{|c|}{ 5-10 cm Layer } \\
\hline $\mathrm{NF}$ & $21.2 \mathrm{ab}$ & $48.9^{\mathrm{ns}}$ & $2.4^{\mathrm{ns}}$ \\
\hline SF & $22.5 \mathrm{a}$ & 53.8 & 2.2 \\
\hline $\mathrm{P} 1-2$ & $21.4 \mathrm{ab}$ & 50.3 & 2.2 \\
\hline P5-7 & $19.4 \mathrm{~b}$ & 69.8 & 3.1 \\
\hline P10-12 & $20.3 \mathrm{ab}$ & 50.0 & 2.8 \\
\hline Average & $21.0 \mathrm{~B}$ & $54.6 \mathrm{~A}$ & $2.5 \mathrm{C}$ \\
\hline
\end{tabular}

Averages followed by the same lower-case letter in the column and capital letter in the line did not differ by the Duncan test with an error margin of $5 \%$; ${ }^{\text {ns }}$ : not significant.

pasture age was less prevalent; in the $5-10 \mathrm{~cm}$ layer, the values for all land use systems were similar.

The $\mathrm{C}$ content reduction with depth was more pronounced in use systems under human influence, mainly pastures. The percent decrease in $\mathrm{C}$ content of the particle-size fractions between the soil surface and the 5-10 cm layer was lowest for the clay fraction: $7 \%$ in $\mathrm{P} 1-2$ to $21 \%$ in NF. For larger particle sizes reduction was greater: $45 \%$ in NF to $66 \%$ in $\mathrm{P} 10-12$ for the $2-53 \mu \mathrm{m}$ fraction and $69 \%$ in NF to $80 \%$ in P1-2 for the 53-2,000 $\mu \mathrm{m}$ fraction.

There was an increasing tendency for soil $\mathrm{C}$ content after substitution of forest by pasture in all fractions studied. The tendency of $\mathrm{C}$ content to increase in the surface layer after forest conversion to pasture observed in this study was also verified by Trumbore et al. (1995), Bernoux et al. (1999), and Desjardins et al. (2004) in the Brazilian Amazon. In a study evaluating the effect of deforestation followed by pasture establishment, carried out in chronosequences of Brachiaria brizantha and Panicum maximum pastures on sandy soils in Rondônia, Moraes et al. (1996) verified that after 20 years, pasture soil C content was 17-20\% higher than in forest soil. In clayey soils in the region of Manaus

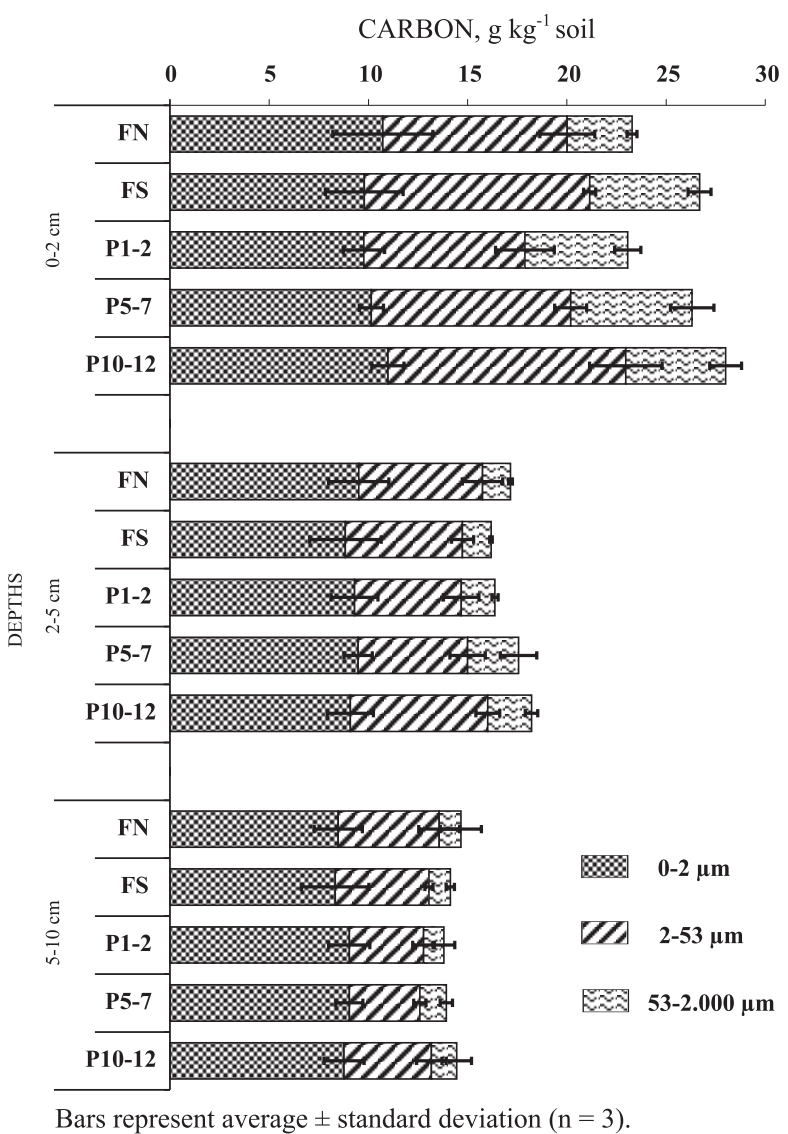

Figure 1. Carbon content in particle-size fractions at different depths in a dystrophic Oxisol, in function of soil use.

(AM), Choné et al. (1991) observed high C inputs derived from pasture into the total $\mathrm{C}$ stock, in the 0 $3 \mathrm{~cm}$ layer.

On the other hand, Falesi (1976) and Desjardins et al. (1994) verified a reduction in $\mathrm{C}$ content after forest substitution by pasture in the Brazilian Amazon, corroborated by Desjardins et al. (2003) in the Peruvian Amazon after maize cultivation. These results indicate that variations in $\mathrm{C}$ content of soil under grass is mainly a function of the land use, as shown in the study of Fearnside \& Barbosa (1998).

In the 53-2,000 $\mu \mathrm{m}$ fraction, substitution of forest provoked a significant change in $\mathrm{C}$ content in the surface layer only. The $\mathrm{C}$ content was lowest in $\mathrm{NF}$, which differed significantly from all other land use systems. In SF, the $\mathrm{C}$ level was 1.7 times higher than in NF; in pasture use systems it was $1.5-1.9$ times higher in P10-12 and P5-7, respectively. However, no such effect was observed for finer fractions, whether in the surface nor in deeper layers.

The soil $\mathrm{C}$ content increase in pastures and secondary forest could be explained by the $\mathrm{C}$ increase in the sand fraction. This could be due to: (1) C increase caused by OM that is little humified, produced 
by the aerial part of the secondary forest and by elevated production, accumulation and cycling of grass roots (Moraes, 1995); (2) and/or by alterations of soil microbial activity, which was reduced in pasture areas compared with forest, decreasing $\mathrm{OM}$ decomposition and mineralization processes, as shown in the study of Melo (2007) for the study area.

Generally, substitution of forest-derived $\mathrm{C}$ by pasture-derived $\mathrm{C}$ occurs more quickly in the soil OM fractions than in finer fractions since the elevated cycling process of grass roots and reduction in decomposition processes favors accumulation of little decomposed fragments in the fraction $>53 \mu \mathrm{m}$ (Feller $\&$ Beare, 1997; Desjardins et al., 2004).

The $\mathrm{C}$ distribution pattern in the particle-size fractions observed in this study was similar to results of Desjardins et al. (1994, 2004), Borges \& Kiehl (1996), Silver et al. (2000) and Roscoe et al. (2001). Generally, the contribution to total soil $\mathrm{C}$ was highest in the finest fraction. This contribution increased with soil depth, varying from $34 \%$ in the surface layer to $67 \%$ in the 5-10 cm layer. On the other hand, C content decreased as depth increased in soil fractions with larger particle sizes. The reduction was greatest in the sand fraction, diminishing from $19 \%$ in the 0 $2 \mathrm{~cm}$ layer to $8 \%$ in the $5-10 \mathrm{~cm}$ layer. These results show a strong correlation between soil texture and $\mathrm{C}$ content, with a higher $\mathrm{C}$ content in finer-textured soils (Desjardins et al., 2004; Luca et al., 2008).

\section{Total soil carbon stock}

In native forest soil, $5.0 \mathrm{Mg} \mathrm{ha}^{-1} \mathrm{C}$ are stocked in the 0-2 cm layer (Figure 2). Carbon stocks in SF and $\mathrm{P} 1-2$ were practically equal $\left(\approx 6.2 \mathrm{Mg} \mathrm{ha}^{-1}\right)$, with a slight increase of $1.2 \mathrm{Mg} \mathrm{ha}^{-1}$ in relation to NF. However, there was an increasing tendency of $\mathrm{C}$ stock with pasture age; the soil C stock of P10-12 in this same layer increased significantly in relation to NF, reaching $8.0 \mathrm{Mg} \mathrm{ha}^{-1}$. In the layers $2-5$ and $5-10 \mathrm{~cm}$, for pasture use systems, soil C stock tended to increase with age, although there was no significant effect of land use system on $\mathrm{C}$ stock. In the surface layer, there was an increase of $60 \%$ in C stock for P10-12 soil compared with NF which decreased to nearly the half (33\%) in the $2-5 \mathrm{~cm}$ layer, and to $12 \%$ in the deepest layer $(5-10 \mathrm{~cm})$.

Part of the $\mathrm{C}$ stock increase could be explained by the greater density of pasture soil. However, calculating the $\mathrm{C}$ stock based on soil mass and not volume, the same tendencies were observed, though to a lesser extent (results not shown). The strong entry of organic residue from the aerial part and the well-developed root system in pasture grass (Roscoe et al., 2001) could also explain this increase. Accumulation of organic residues with larger particle size (Figure 1) and decrease in microbial activity observed in the same areas by Melo (2007) suggest a slowing down of the SOM humification processes.

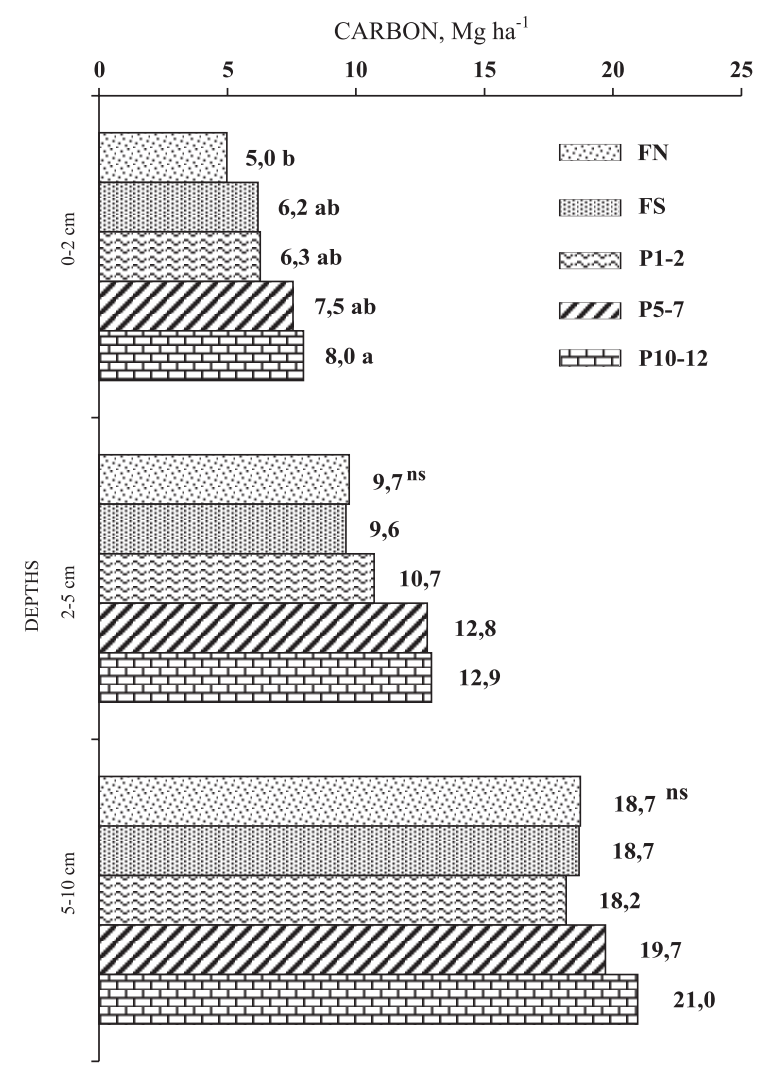

Figure 2. Carbon stock in a dystrophic Oxisol with clayey texture at three depths in function of soil use.

Quantities of C stocked in the surface layer verified in this study exceeded the values observed by Bernoux et al. (1999) in a chronological sequence of forestpasture in Paragominas (PA) in clayey soil. These authors observed a lower $\mathrm{C}$ stock in forest soil in the 0-10 cm layer $\left(21.9 \mathrm{Mg} \mathrm{ha}^{-1}\right)$ whereas in 10 year old pasture, they obtained lower values than for forests $\left(20.4 \mathrm{Mg} \mathrm{ha}^{-1}\right)$. They attributed this reduction to the fact that the area had been used for maize for two years before it was converted to pasture, since according to Cerri (1986), maize returns less plant material than pasture. On the other hand, Bernoux et al. (1999) verified a significant increase in C stock in a 15 year old pasture $\left(26.5 \mathrm{Mg} \mathrm{ha}^{-1}\right)$ where maize had been grown before being used as pasture.

The results in figure 2 show that pastures could be great $\mathrm{C}$ sinks for soil, in agreement with Bernoux et al. (1999), confirming that pasture implantation could lead to an increase in soil $\mathrm{C}$ content over time in the Amazon, as verified by Silver et al. (2000) and Desjardins et al. (2004).

\section{CONCLUSIONS}

1. After deforestation, soil C stocks increased with time of land use as pastures in the layer $0-10 \mathrm{~cm}$, particularly in the layer $0-2 \mathrm{~cm}$. 
2. In the surface layer of pasture soils, slightly decomposed organic residues are accumulated in the sand fraction, while the quantity of $\mathrm{C}$ in the finer fraction did not vary, indicating that the humification processes of SOM had slowed down.

3. No quantitative alterations were observed after deforestation and pasture implementation in the humified organic material associated with clay particles, which represents the majority of organic carbon (OC) in the soil.

\section{ACKNOWLEDGEMENTS}

The authors would like to thank the Institut de Recherche pour le Développement (IRD/France) and $\mathrm{CNPq}$ for financial support (Project Biodiversity and functioning of soil in the context of family farming in the Amazon).

\section{LITERATURE CITED}

ARAÚJO, E.A.; LANI, J.L.; AMARAL, E.F. \& GUERRA, A. Uso da terra e propriedades físicas e químicas de Argissolo Amarelo distrófico da Amazônia Ocidental. R. Bras. Ci. Solo, 28:307-315, 2004.

BALESDENT, J.; BESNARD, E.; ARROUAYS, D. \& CHENU, C. The dynamics of carbon in particle-size fractions of soil in a forest-cultivation sequence. Plant Soil, 201:49$57,1998$.

BERNOUX, M.; FEIGL, B.J.; CERRI, C.C.; GERALDES, A.P.A. \& FERNANDES, S.A.P. Carbono e nitrogênio em solo de uma cronossequência de floresta tropical-pastagem de Paragominas. Sci. Agric., 56:777-783, 1999.

BIRD, M.I.; VEENENDAAL, E.M.; MOYO, C.; LLOYD, J. \& FROST, P. Effect of fire and soil texture on soil carbon in a sub-humid savanna (Matopos, Zimbabwe). Geoderma, 94:71-90, 2000 .

BIRI KASSOUM, B. \& MAITRE D’HOTEL, E. Système agraire d’une localité de front pionnier dans l'état du Pará. Montpellier, CNEARC, 2002. 82p. (Mémoire 1ére année Ecole Supérieure d'Agronomie Tropicale)

BORGES, A.L. \& KIEHL, J.C. Alterações da matéria orgânica de um Latossolo Amarelo álico de Cruz das Almas (BA), pelo cultivo com frutíferas perenes e mandioca. R. Bras. Ci. Solo, 20:313-318, 1996.

CERRI, C.C. Dinâmica da matéria orgânica do solo no agrossistema cana-de-açúcar. Piracicaba, Escola Superior de Agricultura "Luiz de Queiroz" - Universidade de São Paulo, 1986. 197p. (Tese de Livre-Docência)

CHONÉ, T.; ANDREUX, F.; CORREA, J.C.; VOLKOFF, B. \& CERRI, C.C. Changes in organic matter in an Oxisol from the Central Amazonian forest during eight years as pasture determined by $13 \mathrm{C}$ isotopic composition. In: BERTHELIN, J., ed. Diversity of environmental biogeochemistry. Amsterdam, Elsevier, 1991. p.397-405.
CHRISTENSEN, B.T. Physical fractionation of soil and structural and functional complexity in organic matter turnover. Eur. J. Soil Sci., 52:345-353, 2001.

DE REYNAL, V. Agriculturas familiares e desenvolvimento em frente pioneira amazônica. Marabá, LASAT/UFPA/ GRET/UAG, 1995. 48p.

DESJARDINS, T.; ANDREUX, F.; VOLKOFF, B. \& CERRI, C. Organic carbon and ${ }^{13} \mathrm{C}$ contents in soils and soil sizefractions, and their changes due to deforestation and pasture installation in Eastern Amazonia. Geoderma, 61:103-118, 1994.

DESJARDINS, T.; BARROS, E.; SARRAZIN, M.; GIRARDIN, C. \& MARIOTTI, A. Effects of forest conversion to pasture on soil carbon content and dynamics in Brazilian Amazonia. Agric. Ecosyst. Environ., 103:365-373, 2004.

DESJARDINS, T.; CHARPENTIER, F.; PASHANASI, B.; PANDO-BAHUON, A.; LAVELLE, P. \& MARIOTTI, A. Effects of earthworm inoculation on soil organic matter dynamics of a cultivated ultisol. Pedobiologia, 47:835-841, 2003.

EMPRESA BRASILEIRA DE PESQUISA AGROPECUÁRIA EMBRAPA. Centro Nacional de Pesquisa de Solos. Manual de métodos de análise de solo. 2.ed. Rio de Janeiro, 1997. 212p.

FALESI, I. Ecossistema de pastagem cultivada na Amazônia Brasileira. Belém, Embrapa-CPATU, 1976. 193p. (Boletim Técnico, 1)

FEARNSIDE, P.M. \& BARBOSA, R.I. Soil carbon changes from conversion of forests to pasture in Brazilian Amazonia. For. Ecol. Manag., 108:147-166, 1998.

FELLER, C. \& BEARE, M.H. Physical control of soil organic matter dynamics in the tropics. Geoderma, 79:69-116, 1997.

GAVINELLI, E.; FELLER, C.; LARRÉ-LARROUY, M.C.; BACYE, B.; DJEGUI, N. \& NZILA, J.D. A routine method to study soil organic matter by particle-size fractionation: Examples for tropical soils. Comm. Soil Sci. Plant Anal., 26:1749-1760, 1995.

KOUTIKA, L.S.; BARTOLI, F.; ANDREUX, F.; CERRI, C.C.; BURTIN, G.; CHONÉ, T. \& PHILIPPY, R. Organic matter dynamics and aggregation in soils under rain forest and pasture of increasing age in Eastern Amazon Basin. Geoderma, 76:87-112, 1997.

LONGO, R.M. \& ESPÍNDOLA, C.R. Alterações em características químicas de solos da Região Amazônica pela introdução de pastagens. Acta Amaz., 30:71-80, 2000.

LUCA, E.F.; FELLER, C.; CERRI, C.C.; BARTHÈS, B.; CHAPLOT, V.; CAMPOS, D.C. \& MANECHINI, C. Avaliação de atributos físicos e estoques de carbono e nitrogênio em solos com queima e sem queima de canavial. R. Bras. Ci. Solo, 32:789-800, 2008.

LUIZÃO, C.C.R.; COSTA, E.S. \& LUIZÃO, F.J. Mudanças na biomassa microbiana e nas transformações de nitrogênio do solo em uma sequência de idades de pastagens após derruba e queima da floresta na Amazônia Central. Acta Amaz., 29:43-56, 1999. 
MARTINS, P.F.S.; CERRI, C.C.; ANDREUX, F. \& VOLKOFF, B. O solo de um ecossistema natural de floresta localizado na Amazônia Oriental. II. Fracionamento da matéria orgânica do horizonte A. Bol. Museu Paraense Emílio Goeldi. Serie Ci. Terra, 1:79-89, 1989.

MARTINS, P.F.S.; VOLKOFF, B.; CERRI, C.C. \& ANDREUX, F. Consequências do cultivo e do pousio sobre a matéria orgânica do solo sob floresta natural na Amazônia Oriental. Acta Amaz., 20:19-28, 1990

MELO, V.S. Avaliação da qualidade dos solos em sistemas de floresta primária-capoeira-pastagem na Amazônia Oriental por meio de indicadores de sustentabilidade microbiológicos e bioquímicos. Belém, Universidade Federal Rural da Amazônia, 2007. 145p. (Tese de Doutorado)

MIELNICZUK, J.; BAYER, C.; BESAN, F.M.; LOVATO, T.; FERNÁNDEZ, F.F. \& DEBARBA, L. Manejo de solo e culturas e sua relação com os estoques de carbono e nitrogênio do solo. In: CURI, N.; MARQUES, J.J.; GUILHERME, L.R.G.; LIMA, J.M.; LOPES, A.S. \& ALVAREZ V., V.H., eds. Tópicos em ciência do solo. Viçosa, MG, Sociedade Brasileira de Ciência do Solo, 2003. v.3. p.209-248.

MORAES, J.F.L. Propriedades do solo e dinâmica da matéria orgânica associada às mudanças do uso da terra em Rondônia (RO)/ Brasil. Piracicaba, Universidade de São Paulo, 1995. 69p. (Tese de Mestrado)

MORAES, J.F.L.; VOLKOFF, B.; CERRI, C.C. \& BERNOUX, M. Soil properties under Amazon forest and changes due to pasture installation in Rondônia, Brazil. Geoderma, 70:63-81, 1996
RANGEL, O.J.P. \& SILVA, C.A. Estoques de carbono e nitrogênio e frações orgânicas de Latossolo submetido a diferentes sistemas de uso e manejo. R. Bras. Ci. Solo, 31:1609-1623, 2007.

ROSCOE, R.; BUURNMAN, P.; VELTHORST, E.J. \& VASCONCELLOS, C.A. Soil organic matter dynamics in density and particle size fractions as revealed by the ${ }^{13} \mathrm{C} /$ ${ }^{12} \mathrm{C}$ isotopic ratio in a Cerrado's Oxisol. Geoderma, 104:185-202, 2001.

SÁNCHEZ, P.A. Suelos del trópico: Características y manejo. San José, IICA, 1981. 660p.

SILVA, C.A. \& MACHADO, P.L.O.A. Sequestro e emissão de carbono em ecossistemas agrícolas: Estratégias para o aumento dos estoques de matéria orgânica em solos tropicais. Rio de Janeiro, Embrapa Solos, 2000. 23p. (Documentos, 19)

SILVER, W.L; NEFF, J.; McGRODDY, M.; VELDKAMP, E.; KELLER, M. \& COSME, R. Effects of soil texture on belowground carbon and nutrient storage in a lowland Amazonian forest ecosystem. Ecosystems, 3:193-209, 2000.

SIMÕES, L.H.R. Influência da cobertura pedológica na utilização do solo na localidade de Benfica, município de Itupiranga - PA. Belém, Universidade Federal Rural da Amazônia, 2004. 79p. (Tese de Mestrado)

SMITH, T.J. \& BASTOS, J.B. Alterações na fertilidade de um Latossolo Amarelo álico pela queima da vegetação. $R$. Bras. Ci. Solo, 8:127-132, 1984.

TISDALL, J.M. \& OADES, J.M. Organic matter and waterstable aggregates in soils. J. Soil Sci., 33:141-163, 1982.

TRUMBORE, S.E.; DAVIDSON, E.A.; CAMARGO, P.B.; NEPSTAD, D.C. \& MARTINELLI, L.A. Belowground cycling of carbon in forests and pastures of Eastern Amazonia. Global Biochem. Cycles, 9:515-528, 1995. 